\title{
A mesterséges intelligencia fogalmának polgári jogi értelmezése
}

\author{
Artificial Intelligence from the Viewpoint of Civil Law
}

\begin{abstract}
ABSZTRAKT
Jelen tanulmány célja annak vizsgálata, hogy a mesterséges intelligencia fogalma hogyan nyerhet értékelést a polgári jog területén. A témát számos szerző vizsgálja világszerte, s sürgetik annak mielőbbi jogi szabályozását, hiszen a terület napról napra egyre gyorsabban fejlődik, amivel a jog nem tud lépést tartani. Az egyének védelme érdekében pedig kiemelkedően fontos, hogy a fogalom jogi értékelést nyerjen. Ennek első lépése lehet a definíció polgári jog általi meghatározása.
\end{abstract}

Kulcsszavak: mesterséges intelligencia, szoftver, immateriális javak, dolog, jogalany

\begin{abstract}
The aim of this paper to examine the definition of artificial intelligence and how Al can be considered in the field of civil law. The topic is being studied by many authors around the world and they are urging the initiation of legislation. The reason is that technology is rapidly developing, but the legislation cannot cope with this. However, in order to protect individuals, it is important to have a legal assessment of artificial intelligence. As a first step, it might be helpful to define the technology from the viewpoint of civil law.
\end{abstract}

Keywords: artificial intelligence, software, intangible assets, thing, legal personhood

Napjaink technológiai fejlesztéseiben a mesterséges intelligencia (a továbbiakban: $\mathrm{MI}$, illetve $\mathrm{Al}$ ) erőteljes térnyerését tapasztaljuk, s ez a jövőben továbbra is erösödni fog. A mesterséges intelligencia - szinte láthatatlanul - mindennapi életünk meghatározó szereplőjévé vált az ún. chatbotok megjelenésével, vagy a kéretlen elektronikus levelek kiszürése által. Elöbbiek olyan hang- vagy szövegalapú csevegöprogramok, amelyek mesterséges intelligenciával működnek, és a felhasználó által

\footnotetext{
* Dr. Stefán Ibolya, PhD-hallgató, Miskolci Egyetem Deák Ferenc Állam- és Jogtudományi Doktori Iskola, e-mail: stefan.ibolya95@gmail.com. A kutatást az EFOP-3.6.2-16-2017-00007 azonosító számú, Az intelligens, fenntartható és inkluzív társadalom fejlesztésének aspektusai: társadalmi, technológiai, innovációs hálózatok a foglalkoztatásban és a digitális gazdaságban című projekt támogatta. A projekt az Európai Unió támogatásával, az Európai Szociális Alap és Magyarország költségvetése társfinanszírozásában valósul meg.

${ }^{1}$ A napjainkban is használatos kifejezés - angolul artificial intelligence (a továbbiakban: Al) - atyja John McCarthy, az elnevezés 1956-ban született egy Dartmouthban tartott találkozón, amelyen a téma legjelesebb kutatói vettek részt. Az Ml és Al kifejezések egyaránt a mesterséges intelligenciát jelentik, így a továbbiakban szinonimaként alkalmazzuk e rövidítéseket. RusseLL, Stuart J.-NORVIG, Peter: Mesterséges intelligencia Modern megközelítésben. Panem, Budapest, 2005, 14. https://people.inf.elte.hu/fekete/algoritmusok_msc/ wumpus/Russel_Norvig_Ml_2ed.pdf (2020.01.06.).
} 
adott parancsokat hajtanak végre, vagy feltett kérdéseket válaszolnak meg. ${ }^{2}$ Többek között ide tartoznak a Facebook Messenger chatbotjai, ${ }^{3}$ az Amazon intelligens aszszisztense, Alexa, vagy az Apple iOS alkalmazásaként futó, szintén intelligens aszszisztens, Siri. $^{4}$

Felmerülhet a kérdés, hogy mégis mi értelme van az Ml jogi definiálásának, hiszen az megfoghatatlan, leginkább science fiction könyvek, filmek szereplője. Úgy véljük, érdemes az ismeretlen technológiák jogi kihívásaival foglalkozni akkor is, ha azok nem tủnnek az adott pillanatban relevánsnak. A múlt eseményeit szemlélve látható, hogy a technológia folyamatosan és egyre gyorsabb ütemben változik, ám erre a jog csak később tud reagálni, ugyanakkor a mérsékelt felkészültség társadalmi és gazdasági szempontból is fontos. Elengedhetetlen az egyének és jogaik védelme, valamint a gazdasági szempontok szem előtt tartása, hiszen a jogi szabályozás hiánya vagy elégtelensége a gazdasági fejlődés gátja lehet.

Jelen tanulmányban annak feltárására vállalkozunk, hogy a mesterséges intelligencia definíciója hogyan értelmezhető a polgári jog tárgykörében. Ehhez kapcsolódóan fontos vizsgálnunk a Polgári törvénykönyv hatályos szabályait, a jogirodalmi klasszikusokat, valamint (a közös jogi hagyományokra tekintettel) a germán jogrendszer joganyagát. Az elemzés a fogalmi elemekre irányul, amelyhez az analógia eszközét és a jog-összehasonlító módszert alkalmazzuk. Az alapvető kérdésre világszerte számos szerző keresi a választ, hogy az eddig ismeretlen entitás valamilyen módon megragadhatóvá, értékelhetővé váljon a jogrendszer egészében, és szűkebben a magánjog területén is. A végső cél pedig az, hogy az Al által esetlegesen okozott károk vonatkozásában tisztább képet kapjunk arról, hogy ki lesz felelősségre vonható, illetve helytállásra kötelezett. Az MI polgári jogi szempontból való beazonosítása azonban nemcsak a felelősségi kérdések rendezését szolgálhatja. Úgy véljük, hogy az említett technológia elterjedésével, s annak rohamos fejlődésével mindinkább szükséges lesz a mesterséges intelligencia mielöbbi polgári jogi minősítése.

Tanulmányunk célja a különböző definiálási, értelmezési kísérletek összegyűjtése, valamint az, hogy rávilágítsunk azok pozitív, illetve negatív aspektusaira. Az egyes lehetőségekkel kapcsolatos, határozott állásfoglalást a magunk részéről még korainak tartjuk, hiszen ahhoz az uniós joganyag beható ismerete is elengedhetetlen. ${ }^{5}$ Végezetül fontos kitérnünk arra is, hogy a technológia tekintetében Al-optimisták vagyunk: az Ml-re nem problémaként, hanem izgalmas jogi kihívásként tekintünk.

2 SzŰTs Zoltán-Yoo, Jinil: A chatbotok jelensége, taxonómiája, felhasználási területei, erősségei és kihívásai. Információs Társadalom, 2018/2, 43. (DOI: 10.22503/inftars.XVIII.2018.2.3).

${ }^{3}$ AsLI, Arash: How Facebook Messenger Bots Are Revolutionizing Business. Forbes (sajtóhír): https://www.forbes. com/sites/forbestechcouncil/2018/06/06/how-facebook-messenger-bots-are-revolutionizing-business/ (2020. 01. 14.).

${ }^{4}$ MARR, Bernard: Are Alexa and Siri Considered Al? (Blogbejegyzés): https://bernardmarr.com/default.asp? contentID=1830 (2020. 01. 14.).

${ }^{5}$ Lásd: Liability for Artificial Intelligence and Other Emerging Digital Technologies. Report from the Expert Group on Liability and New Technologies - New Technologies Formation. European Union, 2019. (DOI: 10.2838/573689) https://ec.europa.eu/transparency/regexpert/index.cfm?do=groupDetail.groupMeetingDoc\&docid=36608 (2020. 02. 04.). 


\section{Fogalmi alapvetések}

A nevezett technológia pontos jogtudományi definiálása meglehetősen nehéz. Ennek egyik oka, hogy más tudományterületek - informatika, pszichológia, filozófia sem egységesen határozzák meg az Al fogalmát. A másik ok pedig, hogy az egyes szerzők is különböző lényeges elemeket emelnek ki a meghatározásakor. Mindezek alapján tehát elmondható, hogy nem beszélhetünk egységes mesterséges intelligencia fogalomról. Az alábbiakban az MI fogalmát a legmeghatározóbb nézetek szerint tekintjük át.

\subsection{A mesterséges intelligencia mint technológia}

John $R$. Searle az MI fogalmát annak minősége szerint kezelte. Ez alapján beszélhetünk ún. gyenge - weak Al - és erős - strong Al - mesterséges intelligenciáról. Előbbivel intelligensen cselekvő, utóbbival pedig ténylegesen gondolkodó rendszereket jelölnek. ${ }^{6}$

A loannis Revolidis és Alan Dahi szerzőpáros kiindulási alapját a Lordok Háza Mesterséges intelligenciát vizsgáló Különbizottságának jelentése adja, ${ }^{7}$ amelynek nyomán különbséget tesznek a „keskeny”, általános, illetve szuper MI között. ${ }^{8} \mathrm{Az}$ ún. keskeny és általános MI kifejezéseket a gyenge-erős kategóriákkal állítják párhuzamba. ${ }^{9}$ Ezt a megközelítést alkalmazza az Európai Unió fogalommeghatározása is. ${ }^{10}$ A keskeny MI lényege, hogy a gépek képességei hasonlítanak az emberi képességekre. ${ }^{11}$ Ezzel szemben az általános MI már magasabb szintet képvisel, mivel a programnak ténylegesen emberi képességei vannak. ${ }^{12} \mathrm{~A}$ különbség leginkább úgy szemléltethető, hogy a keskeny MI csak bizonyos elöre meghatározott feladatok végrehajtására képes, míg az általános MI képes arra is, hogy saját maga által kitüzött célokat valósítson meg, feladatokat hajtson végre - tehát lényegében gondolkodásra képes. ${ }^{13}$ A szuper MI végső soron sokkal többre képes, mint az emberi agy: túltesz a legokosabb személyeken is, sokkal intelligensebb szinte minden területen. ${ }^{14}$

${ }^{6}$ CsÁJI Balázs Csanád: A mesterséges intelligencia filozófiai problémái. (kézirat), ELTE Filozófia szak, $2002,4$. http://old.sztaki.hu/ csaji/CsBCs_MI.pdf (2020. 01. 14.).

${ }^{7}$ Lords Committee: Al in the UK: Ready, willing and able? House of Lords Select Committee on Artificial Intelligence, Parliament of the United Kingdom. Report Session 2017-19. https://publications.parliament.uk/pa/ Id201719/ldselect/ldai/100/100.pdf (2020. 01. 14.).

${ }^{8}$ ReVolidis, loannis-DAHI, Alan: The Peculiar Case of the Mushroom Picking Robot: Extra-contractual Liability in Robotics. In: Corrales, Marcelo-Fenwick, Mark-Forgó, Nikolaus (eds.): Robotics, Al and the Future of Law. Springer, Singapore, 2018, 59. (DOI: 10.1007/978-981-13-2874-9_3).

9 TURNER, Jacob: Robot Rules - Regulating Artificial Intelligence. Palgrave Macmillan, Cham, 2018, 6. (DOI: 10.1007/978-3-319-96235-1).

10 Independent High-Level Expert Group on Artificial Intelligence: A Definition of Al: Main Capabilities and Disciplines. 8 April 2019., 5.

${ }^{11}$ ReVOLIDIS-DAHI: i. m., 59. Artificial Narrow Intelligence (ANI): „which can be defined as »the ability of machines to resemble human capabilities in narrow domains. "”.

12 ReVolidIS-DAHI: i. m., 59. Artificial General Intelligence (AGI): „would have human capabilities across number of domains.".

13 TURNER: i. m., 6.

${ }^{14}$ REVOLIDIS-DAHI: i. m., 59. Artificial Super Intelligence (ASI): ,it is an intelligence that is »much smarter than the best human brain in practically every field, inculding scientific creativity, general widsom and social skills. «". 
A szuper mesterséges intelligencia ugyan távolinak tűnhet, mégis számos kutatás alapjául szolgál. Nick Bostrom három fajtáját különbözteti meg az ún. szuperintelligenciának:

1. Gyors szuperintelligencia: olyan rendszer, melynek képességei az emberi elmével azonosak, de annál lényegesen gyorsabbak.

2. Kollektív szuperintelligencia: olyan több, kisebb intelligenciából álló rendszer, amelyek teljesítménye összeadódik, s azok összessége meghaladja az általános mesterséges intelligenciával rendelkező rendszerek teljesítményét.

3. Minőségi szuperintelligencia: olyan rendszer, amelynek gyorsasága közel azonos az emberével - vagy annál gyorsabb is lehet -, ám annak minősége jóval magasabb. A fogalom lényege legegyszerübben úgy szemléltethető, ha elképzeljük az emberek és az állatok (például delfinek, elefánt) közötti intellektusbeli különbséget. Ilyen lenne az ember és a minőségi szuperintelligencia közötti különbség is. ${ }^{15}$

Véleményünk szerint a legfontosabb MI-fogalom az Európai Unió által meghatározott, hiszen az egyes tagállamoknak az ún. MI akciótervek kidolgozásakor figyelemmel kell lenniük az uniós joganyagra, iránymutatásokra. Az uniós fogalom korábban az alábbiak szerint hangzott: „A mesterséges intelligencia intelligens viselkedésre utaló rendszereket takar, amelyek konkrét célok eléréséhez elemzik környezetüket és - bizonyos mértékü autonómiával - intézkedéseket hajtanak végre."16 A mesterséges intelligenciával müködő rendszerek vonatkozásában különbséget tesznek a szoftverek (például hang- és arcfelismerő rendszerek) és hardveres eszközök (például fejlett robotok) között. ${ }^{17}$

A 2018 júniusában kiadott dokumentumban szereplő fogalmat azonban hamar aktualizálni kellett, ezért a szakértői csoport a definíció változtatására tett javaslatot. Az új fogalom szerint a mesterséges intelligencia alapú rendszerek olyan, ember által tervezett szoftverek (és lehetőség szerint hardveres alapú rendszerek), amelyek meghatározott komplex célok elérése érdekében cselekszenek a fizikai vagy digitális dimenzióban, és elemzik környezetüket adatgyűjtés, az összegyűjtött rendszerezett vagy rendszertelen adatok értelmezése, tudásalapú érvelés vagy az információfeldolgozás által, majd a származtatott adatokból a legjobb, legmegfelelőbb cselekvést valósítják meg a meghatározott cél elérése érdekében. A mesterséges intelligencia rendszerek használhatnak szimbolikus szabályokat, megtanulhatnak numerikus modellt, és adaptálhatják viselkedésüket azáltal, hogy elemzik, milyen hatással volt korábbi cselekvésük a környezetükre. Az MI mint tudományág, tudományos diszciplína, számos felfogást és technikát tartalmaz, úgymint gépi tanulás (például mélytanulás és megerősítéses tanulás), gépi érvelés (tervezés, ütemezés, ismeretábrázolás és érvelés, keresés és optimalizálás) és robotika (kontroll, észlelés, érzékelés, szenzorok és müködtető elemek, beavatkozó szervek, minden más technika integrálása a kiber-fizikai rendszerekbe). ${ }^{18}$

\footnotetext{
15 Bostrom, Nick: Szuperintelligencia. Ad Astra, Budapest, 2015, 89-96.

${ }^{16}$ Mesterséges intelligencia Európa számára - A Bizottság közleménye az Európai Parlamentnek, az Európai Tanácsnak, a Tanácsnak, az Európai Gazdasági és Szociális Bizottságnak és a Régiók Bizottságának. $\operatorname{COM}(2018) 237$ final/2 (a továbbiakban: $\operatorname{COM}(2018) 237$ final/2). Brüsszel, 2018. 06. 26., 1.

$17 \operatorname{COM}(2018) 237$ final/2, 1.

18 „Artificial intelligence (Al) systems are software (and possibly also hardware) systems designed by humans that, given a complex goal, act in the physical or digital dimension by perceiving their environment through
} 


\subsection{Az MI, a robot és a robotika elhatárolása}

A robot kifejezés szláv eredetü, jelentése munkavégzéssel kapcsolatos. Az Encyclopaedia Britannica meghatározása szerint olyan automatikusan müködő gép, amely helyettesíti az emberi erőfeszítést, habár az emberi lényre megjelenésében vagy feladatok ellátásában nem hasonlít. Ehhez szorosan kapcsolódik a robotika mint olyan müszaki szakterület, ami a robotok tervezésével, kivitelezésével és múködtetésével foglalkozik. ${ }^{19}$ „A robotok olyan fizikai ágensek, amelyek a fizikai világ megváltoztatásával oldanak meg feladatokat." ${ }^{20}$ A feladatok végrehajtása érdekében beavatkozó szervekkel és érzékelőkkel szerelik fel őket. ${ }^{21}$

Ezzel szemben érdemes megemlíteni a testetlen robotok fogalmának megjelenését. A kifejezés az MI és a robot fogalmak összemosódásának eredményeként, illetve a robot fizikai létének, emberszerű megjelenésének háttérbe szorulásával született meg. Lényege, hogy ez utóbbi ismérvek hiányában is beszélhetünk robotokról. ${ }^{22}$

\section{Az MI jogi megítélése}

Az Al jogi megítélése kapcsán a szakirodalomban három irányzat rajzolódik ki, amelyekben az Al mint szoftver, mint jogalany, illetve az Al mint dolog nyer értékelést. A technológia megítélése kapcsán további szükítésre van lehetőség, ha kifejezetten a római jogi alapokhoz térünk vissza, amely a szabályozás tekintetében pusztán dolgokban és jogalanyokban gondolkodott. Álláspontunk szerint az MI jogi értelmezése kapcsán érdemes mind a három irányzatot vizsgálni, illetve ezt kettőre szűkíteni. Ennélfogva vizsgáljuk a szoftvert, s annak dologi jellegét is tanulmányozzuk, majd pedig áttérünk a jogalanyiság kérdésére. A mesterséges intelligencia jogi relevanciával bíró tulajdonságai közül, a teljesség igénye nélkül, csak néhányat kívánunk kiemelni. A technológia immateriális jellege, testi kiterjedéstől független volta a szoftver léte alapján értékelhető. Az önálló cselekvésre, s fejlődésre való képessége okán pedig párhuzamba állítható a biológiai lényekkel, ami a jogalanyiság kérdésköre kapcsán

data acquisition, interpreting the collected structured or unstructured data, reasoning on the knowledge, or processing the information, derived from this data and deciding the best action(s) to take to achieve the given goal. Al systems can either use symbolic rules or learn a numeric model, and they can also adapt their behaviour by analysing how the environment is affected by their previous actions.

As a scientific discipline, Al includes several approaches and techniques, such as machine learning (of which deep learning and reinforcement learning are specific examples), machine reasoning (which includes planning, scheduling, knowledge representation and reasoning, search, and optimization), and robotics (which includes control, perception, sensors and actuators, as well as the integration of all other techniques into cyber-physical systems)." Independent High-Level Expert Group on Artificial Intelligence: A Definition of Al: Main Capabilities and Disciplines. Brussels, 2019. 04. 08. 6.

${ }^{19}$ Encyclopaedia Britannica: Robot - Technology. https://www.britannica.com/technology/robot-technology (2019. 12. 22.).

20 Russell-Norvig: i. m., 795.

21 RusSelL-NoRvig: i. m., 795.

22 ZőDI Zsolt: Platformok, robotok és a jog - Új szabályozási kihívások az információs társadalomban. Gondolat, Budapest, 2018, 62-63. 
lehet érdekes. A mesterséges intelligencia jogi értelmezése szükségszerü feladat, hiszen a technológia már mindennapjaink részévé vált, s nemzetközi szinten is az érdeklődés középpontjába került. ${ }^{23}$

\subsection{Megítélése a hatályos szabályozás alapján - az Al mint szoftver}

Amennyiben a mesterséges intelligenciára szoftverként tekintünk, az a hatályos hazai szabályok szerint a szerzői jogról szóló 1999. évi LXXVI. törvény (a továbbiakban: Szjt.) hatálya alá tartozik. Az Szjt. az alábbiak szerint adja meg a szoftver fogalmát: a számítógépi programalkotás és az ahhoz kapcsolódó dokumentáció, ,„akár forráskódban, akár tárgykódban, vagy bármilyen más formában rögzített minden fajtája, ideértve a felhasználói programot és az operációs rendszert is". ${ }^{24} \mathrm{Az}$ Szjt. nem tartalmaz a szoftver általi károkozásra és a felelősségre vonatkozó szabályokat. Ennek oka, hogy a gyakorlatban azt a felek közti felhasználási szerződés rendezi, az esetek nagy részében a károkért való felelösséget a felhasználó személyre telepítve. ${ }^{25}$

Az Szjt. kapcsán felmerülő probléma leginkább az, hogy a szerző, valamint az általa létrehozott mủ védelmére helyezik a hangsúlyt. A törvény célja kifejezetten ez, azonban a mesterséges intelligencia kapcsán ez nem elégséges. Az MI-vel kapcsolatban felmerülő probléma, hogy bár szoftverként szerzői münek minősül, de olyan cselekvésekre is képes, amelyekre azelőtt más programok nem voltak képesek. Az MI tehát több mint egy átlagos szoftver, mivel emberszerủ cselekvő.

Az MI szoftver-jellege kapcsán a további vizsgálódás kétirányú lehet. Egyrészt vizsgálható a szoftver mint az immateriális javak körébe tartozó vagyontárgy, másrészt pedig az Al dologi minősége.

\subsubsection{A mesterséges intelligencia egyéb vagyontárgyként való szabályozása}

Az Európai Bizottság által 2018-ban kiadott „A közös európai adattér kialakitása felé"26 és a „Mesterséges intelligencia Európa számára" elnevezésű dokumentumok célkitúzései között szerepel egy egységes digitális piac kialakítása. Ez egyrészt azért is szükséges, mert az Al alapvetően adatokkal tud dolgozni, és a fejlesztések

\footnotetext{
${ }^{23}$ AtABEkov, Atabek-YAStrebov, Oleg: Legal Status of Artificial Intelligence Across Countries: Legislation on the Move. European Research Studies Journal, 2018/4. (DOI: 10.35808/ersj/1245); DoH-DJANHOUNDY, Théo: Le statut juridique de l'intelligence artificielle en question. https://www.researchgate.net/publication/337438902 Le_statut_juridique_de_l'intelligence_artificielle_en_question (2020.01. 14.).

JAYNES, Tyler L.: Legal personhood for artificial intelligence: citizenship as the exception to the rule. Al \& Society, 2019 June: https://link.springer.com/article/10.1007/s00146-019-00897-9 (2020. 01. 14.) (DOI: 10. 1007/s00146-019-00897-9).

24 Szjt. 1. § (2) bekezdés c) pont.

${ }^{25}$ ESzTERI Dániel: A mesterséges intelligencia magánjogi viselkedéséért való magánjogi felelősség az online játékokban. Pályamunka, Budapest, 2014. https://jogaszvilag.hu/a-jovo-jogasza/a-mesterseges-intelligenciaviselkedeseert-valo-maganjogi-felelosseg-az-online-jatekokban/ (2020. 01. 15.).

${ }^{26}$ A közös európai adattér kialakitása felé - A Bizottság közleménye az Európai Parlamentnek, a Tanácsnak, az Európai Gazdasági és Szociális Bizottságnak és a Régiók Bizottságának. COM(2018) 232 final, Brüsszel, 2018. 04. 25., 2.
} 
során elengedhetetlen, hogy megfelelő mennyiségü és minőségü adat álljon rendelkezésre. Másrészt, az ún. európai adatgazdaság megvalósítása miatt is fontos, amelyről 2017-ben adott ki közleményt az Európai Bizottság. Az adatgazdaságot a dokumentum az alábbiak szerint definiálja:

Az adatgazdaság az adatpiacnak (azaz annak a piacnak, ahol a nyers adatokból származó digitális adatok termékekként vagy szolgáltatásokként gazdát cserélnek) a teljes gazdaságra kifejtett általános hatását fejezi ki. Ide tartozik a digitális technológiák révén keletkező adatok létrehozása, gyűjtése, tárolása, feldolgozása, terjesztése, elemzése, kidolgozása, szolgáltatása és felhasználása. ${ }^{27}$

Az adatgazdaság kiépítésének eredményeként új munkahelyek létesülnek majd, s ezáltal várhatóan a GDP is növekedni fog.

Hazánk az uniós szabályozással összhangban alkotta meg Magyarország MIstratégiáját, amelynek keretében adatvagyon-ügynökség felállítását és adatpiactér létrehozását tervezik. ${ }^{28} \mathrm{~A}$ mesterséges intelligencia mint vagyontárgy, vagyonelem, valószínűsíthetően az adatgazdaság létrehozása miatt nyerhet jogi értékelést, legalábbis erre utal az uniós joganyag és a hazai Mesterséges Intelligencia Koalíció közleménye. A továbbiakban ezen információk tükrében vizsgáljuk az MI-t mint vagyontárgyat, gazdasági és jogi szempontból egyaránt.

A vállalkozók pénzügyi beszámolójának alapvető részét képező mérlegben eszközként kell kimutatni a vállalkozó müködését szolgáló befektetett eszközöket és a forgóeszközöket (ezek mind olyan jószágok, amelyeket a polgári jog összefoglalóan vagyontárgyaknak nevez), forrásként pedig különösen a saját tőkét és a kötelezettségeket (azaz az idegen forrásokat). ${ }^{29}$

A számviteli törvény alapján az eszközök körébe tartoznak az immateriális javak, e kategórián belül pedig többek között megtalálhatóak a szellemi termékek is. ${ }^{30}$ A szellemi termékek széles köréből most csak a szerzői jogvédelemben részesülő szerzői műveket és szomszédos jogokat kívánjuk kiemelni, hiszen ezek között nevesíti a jogszabály a szoftvereket. ${ }^{31}$ Ahogyan már kitértünk arra, az Al a hatályos szabályozás szerint szoftvernek minősül, így az Szjt. hatálya alá tartozik. Mindezeket egybevetve megállapítható, hogy az MI akár értelmezhető vagyontárgyként, az immateriális javak körébe tartozó eszközként is.

Kiemelendő, hogy a mesterséges intelligencia vagyontárgyként való azonosítása nem az adatok, adatvagyon miatt történik. A minősítésben sokkal nagyobb szerepe

${ }^{27}$ Az európai adatgazdaság kiépítése - A Bizottság közleménye az Európai Parlamentnek, a Tanácsnak, az Európai Gazdasági és Szociális Bizottságnak és a Régiók Bizottságának. COM(2017) 9 final, Brüsszel, 2017. 01. 10., 1.

${ }^{28} 2020$ végére akár százezren szerezhetnek alapismereteket a Mesterséges Intelligenciáról Magyarországon. https://www.kormany.hu/hu/innovacios-es-technologiai-miniszterium/hirek/2020-vegere-akar-szazezrenszerezhetnek-alapismereteket-a-mesterseges-intelliganciarol-magyarorszagon (2019. 12. 28.).

29 GÁRDos István: A vagyontárgy és a vagyon fogalma a Ptk.-ban. Gazdaság és Jog, 2018/11, 5.

30 2000. évi C. törvény a számvitelröl, 1. számú melléklet, A mérleg előírt tagolása - A; B változat.

31 2000. évi C. törvény, 25. $§(7)$ bekezdés $b$ ) pont. 
van annak, hogy a gyakorlatban, a gazdasági életben a szoftver az immateriális javak körébe tartozó vagyontárgy, ahogyan a jogszabály is rendezi, hiszen sok esetben valóban fizikai kiterjedés nélkül jelenik meg. Az MI vagyontárgykénti felfogása tehát leginkább a gazdasági, piaci szempontok érvényesüléséhez köthető.

\subsubsection{Sajátos megközelítés - a szellemi termék mint dolog}

A hatályos polgári jogi szabályozás értelmében dolog alatt a fizikai kiterjedéssel bíró tárgyakat értjük. ${ }^{32}$ Ugyanakkor már a korábbi jogirodalomban is volt ettől eltérő álláspont a szellemi termékek kapcsán. Almási Antal A dologi jog kézikönyve címü kétkötetes müvében a dolog fogalma alá vonta a szellemi termékeket is. Ahogyan ő fogalmazott: „A szellemi termékek a vagyoni jogosultságoknak, az egyszemélyü jogosultságoknak (személyiségi jogoknak és immateriális jogoknak) és e révén a dologi jogosultságoknak is tárgyai." 33 A jogtárgyak körében többek között említette a zenemüveket, a zenés színműveket és a mozgó fényképészeti müveket. Álláspontja szerint a szellemi termékek minősége mutatja, hogy a dologi sajátosságok, ismérvek mennyiben állnak fenn az adott szellemi termék vonatkozásában, s maga a jogszabály mondja ki, hogy az tulajdon, birtok vagy idegen dologbeli jogosultság tárgya-e. ${ }^{34}$

A német jogirodalomban egyes szerzők (például Michael König és Claus D. Müller) elvetették a szoftver dologként való azonosítását, míg mások (például HansWerner Moritz) a dolog fogalmának kiterjesztése mellett érvelnek a technológiai változásokra hivatkozva. ${ }^{35} \mathrm{~A}$ vitát eldönteni látszik a német Szövetségi Legfelsőbb Bíróság által 2006. november 15-én hozott ítélet, amelyben kimondták, hogy a szoftvert dolognak kell tekinteni. ${ }^{36}$

\subsection{Az MI mint dolog}

A továbbiakban a dolog fogalmára és az arra vonatkozó törvényi rendelkezések vizsgálatára koncentrálunk a mesterséges intelligencia vonatkozásában. Jelen részben érdemes néhány szót szólni a termékfelelősségről is. Felmerülhet ugyanis, hogy az Al dologi minőségének vizsgálata helyett egyszerübb lehet azt termékként kezelni, s károkozás esetén a termékfelelősségi szabályokat alkalmazni. Az Európai Unió Bizottsága a jövőben iránymutatást kíván kidolgozni a termékfelelősségi szabályok megfelelő értelmezésére a mesterséges intelligencia vonatkozásában. ${ }^{37}$

\footnotetext{
32 2013. évi V. törvény a Polgári törvénykönyvröl (a továbbiakban: Ptk.), 5:14. § (1) bekezdés.

${ }^{33}$ Almásı Antal: A dologi jog kézikönyve, I. kötet. Tébe Könyvtár, Budapest, 1928, 77.

${ }^{34}$ AlmÁsı: i. m., 76-81.

35 DudÁs Ágnes: A szoftver szerzői jogi védelme II. Iparjogvédelmi és Szerzői Jogi Szemle, 2005/6.

${ }^{36}$ A BGH XII ZR 120/04. számú ítélete.

${ }^{37}$ Mesterséges intelligencia: a Bizottság felvázolja a beruházás ösztönzésére és az etikai iránymutatások kidolgozására vonatkozó európai megközelítést. https://ec.europa.eu/commission/presscorner/detail/hu/ IP_18_3362 (2020.01.06.).
} 


\title{
2.2.1. A klasszikus értelemben vett dolog fogalom vizsgálata
}

A régebbi jogirodalom szerint a dolognak két lényeges ismérve van: a fizikai kiterjedés és a lehatárolhatóság (hiszen ami végtelen, az nem hajtható emberi uralom alá) ${ }^{38} \mathrm{~A}$ Polgári törvénykönyv jelenleg az alábbiak szerint határozza meg a dolog fogalmát: „a birtokba vehető testi tárgy tulajdonjog tárgya lehet”. 39 „A »birtokba vehető" jelző alatt a polgári jog tudománya sokáig az emberi uralom alá hajthatóságot értette." ${ }^{\prime 40}$ Ez két dolgot jelentett, $\mathrm{s}$ jelent napjainkban is a normaszöveg alapján. Egyrészt azt, hogy a dolognak fizikai kiterjedéssel kell rendelkeznie, másrészt a jogi lehetőséget arra vonatkozóan, hogy az adott dolgot valaki birtokba vehesse. ${ }^{41}$ Menyhárd Attila a birtokba vehetőség kapcsán úgy fogalmaz, hogy az „testi jelleget és a személyek számára való elérhetőséget, a birtokba vétel absztrakt lehetőségét jelenti". ${ }^{42}$

A Polgári törvénykönyvben szereplö dolog fogalom kialakulására hatott a res corporales és res incorporales közötti római jogi különbségtétel. Már a rómaiak is különbséget tettek testetlen dolgok és fizikai kiterjedéssel bíró, testi dolgok között; előbbiek tulajdonjog tárgyai, utóbbiak egyéb jogok lehetnek. A hazai szabályozás értelmében, amely szintén római jogi alapokon nyugszik, dolognak kizárólag a res corporales minősül. ${ }^{43}$ Abban az esetben, ha kizárólag a szoftverre, annak fogalmára koncentrálunk, úgy tünhet, hogy az nem minősülhet dolognak, mivel az algoritmusokból, forráskódokból és különféle dokumentációkból áll, s mint ilyen, nem rendelkezik fizikai kiterjedéssel, tehát mint „testetlen dolog” jelenik meg. Ugyanakkor ez mégsem olyan egyértelmü, ha arra gondolunk, hogy a szoftver mint program egymagában nem képes müködésre: ahhoz, hogy célját betöltse, szükség van egy gépre, technikai eszközre, adathordozóra, amelyen a program futtatható. Ez alapján tehát elmondható, hogy a cél elérése érdekében esszenciális követelmény valamiféle fizikai eszköz, testi tárgy, ennélfogva dologi jellege akár elfogadható is lenne.

Már Katona Mór is úgy látta, hogy bár a dolognak fizikai kiterjedéssel kell rendelkeznie, mégis dologgá válhat az, ami nem tapintható, eredetileg materiálisan nem jelenik meg.

\begin{abstract}
Amennyiben a hang, beszéd, ének ma felfogható és tetszésszerinti időben később feléleszthető, ez is dolog lesz, de csak a készülék révén. A készülék segítségével rögzíthető a zene, ének, beszéd hangja, tehát a készülékhez, mint dologhoz tapad a hang, a készülékben rejlik a visszaadható hanghullám. ${ }^{44}$
\end{abstract}

${ }^{38}$ KATONA Mór: Általános tanok. In: Fodor Ármin (szerk.): Magyar Magánjog. II. kötet, Dologjog. Singer és Wolfner, Budapest, 1899-1905, 14-15.

39 Ptk. 5: 14. § (1) bekezdés.

40 JuhÁsz Ágnes-Leszkoven László-PuszTAhelyı Réka: Új Magyar Polgári Jog - Dologi jog. Novotni Alapítvány, Miskolc, 2014, 37.

41 JUHÁSZ-LESZKOVEN-PUSZTAHELYI: i. m., 37.

42 MENYHÁRD Attila: Dologi jog. ELTE Eötvös, Budapest, 2014.

${ }^{43}$ MenYHÁRD, Attila: i. m.

${ }^{44}$ Katona: i. m., 15. 
A klasszikus megközelítésnél maradva a mesterséges intelligencia szoftverként mint „testetlen dolog” jelenhet meg fizikai kiterjedés hiányában. A magyar szabályozás korábban sem fogadta el expressis verbis a testetlen dolgokat klasszikus értelemben vett dologként. Ennek ellenére említésre méltó Wenzel Gusztáv álláspontja, aki különbséget tett testi és testetlen dolgok között, igaz, utóbbiak alatt a különböző jogokat, jogosítványokat értette. Az általa alkotott (erősen osztrák hatást mutató) dolog fogalomból mégis kitűnik, hogy azt nem pusztán a fizikai megjelenésre korlátozta, hanem annak funkciója, célja is mérvadó volt: „Dolog alatt azt értjük, ami általában vagyonunk tárgya lehet - különösen pedig ami a személyül vett emberektől különbözik s birtokoltatván ezeknek használatára szolgál."45

A hazai szabályozáshoz hasonlóan a német Polgári Törvénykönyv a dologi minőség kapcsán megköveteli a fizikai kiterjedést. ${ }^{46}$ Ezzel szemben az Osztrák Polgári Törvénykönyv (a továbbiakban: Optk.) nem értelmezi olyan szigorúan a dolog fogalmát. ${ }^{47}$ Az Optk. 285. § szerint dolog mindaz, ami a személytöl különbözik és az emberek haszná(latá)ra szolgál. A meghatározásból világosan kitűnik, hogy a dolog fogalmát sokkal szélesebb körben értelmezik, s azt nem csupán a testi dologgal azonosítják. Az Optk. továbbmegy, mikor azt mondja a 292. §-ban, hogy a testetlen dolgok az érzékek alá nem eső dolgok, ${ }^{48}$ például vadászati, halászati és minden más jogok, de az újabb irodalom ide sorolja az elektromos áramot és a szoftvereket is. ${ }^{49}$ A dolog fogalmának tágabb értelmezése tekintetében hasonló elgondolás jelenik meg a svájci Polgári Törvénykönyvben is. Eszerint „az emberi uralom alá hajtható, személytelen, önálló testi tárgyakat kezelik dologként, ám itt nem a fizikai 'testiség'en van a hangsúly, hanem a gazdasági funkción...", 50 így analógia útján a dolog fogalma más javakra, például a természeti erőkre is kiterjeszthető. ${ }^{51}$

A fentiek alapján tehát a mesterséges intelligencia akár klasszikus értelemben vett dologként is értelmezhető a technológia megfelelő alkalmazásához szükséges eszközök miatt.

\subsubsection{Az analógia alkalmazásának lehetősége - a rendhagyó dolgok körének kiterjeszthetösége}

Az analógia alkalmazása kapcsán előbb az emberi uralom alá hajtható természeti erökre, majd pedig az állatokra térünk ki. A hatályos szabályozás értelmében a do-

\footnotetext{
45 Wenzel Gusztáv: A magyar magánjog rövid áttekintése. Pfeifer Ferdinánd, Budapest, 1877, 26.

${ }^{46}$ Ellenberger, Jürgen: Abschnitt 2. Sachen und Tiere. In: Palandt (hg.): Kommentar zum BGB. Beck, München, 2019, 70.

${ }^{47} \mathrm{KocH}$, Bernard A.: Product Liability 2.0 - Mere Update or New Version? In: Lohsse, Sebastian-Schulze, ReinerStaudenmayer, Dirk (eds.): Liability for Artificial Intelligence and the Internet of Things. Münster Colloquia on EU Law and the Digital Economy IV. Nomos, Baden-Baden, 2019, 103. (DOI: 10.5771/9783845294797-97).

${ }^{48}$ ABGB § 292: „Körperliche Sachen sind diejenigen, welche in die Sinne fallen; sonst heißen sie unkörperliche; z. B. das Recht zu jagen, zu fischen und alle andere Rechte."

${ }^{49}$ BINDER, Martin: Sachenrecht - Theorie und systematisch aufbereitete OGH-Fälle. Verlag Österreich, Wien, 2003, 34.

${ }^{50}$ MENYHÁRD Attila: Észrevételek és javaslatok az új Polgári Törvénykönyv dologi jogi koncepciójának kiegészítéséhez. Polgári Jogi Kodifikáció, 2002/5-6, 9.

51 MENYHÁRD: i. m., 9.
} 
log módjára hasznosítható természeti erőkre és az állatokra is a dologra vonatkozó szabályokat kell alkalmazni, utóbbiak esetén az állatok természetére vonatkozó szabályokat is figyelembe kell venni. ${ }^{52}$

Az említett természeti erők körébe tartozik többek között a szél-, víz- vagy gázenergia, amelyek közös jellemzője gazdasági hasznosíthatóságuk..$^{53} \mathrm{~A}$ dolog fogalmának természeti erőkre történő kiterjesztése a technológiai fejlődés és a gazdasági-társadalmi változások hatására jelent meg, ezt megelőzően szinte elképzelhetetlen volt a fogalom efféle kiterjesztő értelmezése. A villamos áram jogosulatlan használata ugyanis csak oly módon volt szankcionálható, hogy azt dolognak minősítették, s ezáltal a lopás büntetőjogi tényállásának tárgyává tették.

A felhívott törvényhely (1907: III. t. c. 2. §-a) a villamos áramot és a technikai célokra értékesithető minden egyéb erőt (energiát) a bármely módon való eltulajdonítása, úgyszintén a szándékos és jogtalan megrongálása vagy megsemmisitése szempontjából helyezte az idegen ingó vagyon megrongálására illetve a lopásra vonatkozó büntetőjogi oltalom alá. ${ }^{54}$

Amennyiben közelebbröl is megvizsgáljuk az emberi uralom alá hajtható természeti eröket, láthatjuk, hogy fizikai formában azok sem testesülnek meg. Az elektromos áram dologi jellege is áramkörön, vezetékeken való jelenléttel valósulhat meg, önmagában nem. Ahhoz, hogy a hozzá kapcsolódó előnyök érvényesüljenek, gazdaságilag hasznosítható legyen, fizikai kiterjedéssel kell rendelkeznie. Ez alapján akár az analógia alkalmazása is elképzelhető lenne a mesterséges intelligencia vonatkozásában, hiszen ahogyan arra korábban utaltunk, céljának betöltéséhez szükségesek bizonyos materiális eszközök.

A jogirodalomban egyes szerzők vélekedése szerint az állatok és a robotok között párhuzam vonható, föleg azon fejletlenebb eszközök tekintetében, amelyek még önálló döntésre képtelenek. Álláspontjuk szerint tehát az állatokra (az állatok általi károkozásra) vonatkozó szabályok alkalmazhatóak a robotokra is. A common law az állatok tekintetében két csoportot különböztet meg: a ferae naturae és a mansueate naturea kategóriáját. Elöbbi a természetüknél fogva vadállatokat takarja, s azok károkozása esetén az állattartót általános felelősség terheli. Utóbbiak a háziasított állatok, amelyek kapcsán az állattartó nem általánosságban, hanem csak meghatározott esetekben vonható felelősségre - például gondatlanság esetén. Ioannis Revolidis és Alan Dahi egy példával illusztrálja álláspontját. Ha egy pásztor jól tartott kutyája darázscsípés miatt megharap valakit, és ezzel sérülést okoz neki, a pásztor a kártérítési igények tekintetében kimentéssel élhet. A szerzőpáros álláspontja szerint az állat helyettesíthető a robottal. Ugyanakkor a példából világosan kitűnik, hogy

52 Ptk. 5: 14. § (2) A dologra vonatkozó szabályokat megfelelően alkalmazni kell a pénzre és az értékpapírokra, valamint a dolog módjára hasznosítható természeti erőkre. Ptk. 5: 14. § (3) A dologra vonatkozó szabályokat az állatokra a természetüknek megfelelő eltéréseket megállapító törvényi rendelkezések figyelembevételével kell alkalmazni. (A Ptk. eme rendelkezésével az LXXIV. fejezetben taglalt, az állatok károkozásáért való felelősség szabályaira utal.)

53 JuHÁsZ-LesZKoven-PuszTAHELYI: i. m., 38.

54 AlmÁsı: i. m., 72. 
az állatok esetén kiszámíthatatlan természetük a meghatározó, ám a robotok és az MI esetében nem beszélhetünk kiszámíthatatlan viselkedésröl, a müködési hibák kiküszöbölése és lecsökkentése pedig alapvető elvárás velük szemben. ${ }^{55} \mathrm{~A}$ szerzők itt kifejezetten a fizikai kiterjedéssel rendelkező, Ml által vezérelt robotok kapcsán vizsgálódnak, ám az eszköz lényegét az Al adja, ami álláspontunk szerint nem elhanyagolható. Mindezeket egybevetve az analógia alkalmazásának lehetősége felmerül ugyan, de annak alkalmazása nem biztos, hogy helyénvaló lenne.

\subsection{Az Al mint a jogalany, jogi személyiséggel rendelkező entitás}

A jogalanyiság kérdése meglehetősen komplex az említett technológia vonatkozásában. Napjainkban egyre nagyobb az igény az emberi test technológia általi „feljavítására", ami a későbbiekben hatással lehet a jogalanyiságra is. ${ }^{56}$ Leginkább a robotok kapcsán merül fel a jogalanyiság kérdése, ám mivel a klasszikus „robot” definíció megdőlni látszik - a testetlen robotok és az erős mesterséges intelligencia megjelenése miatt -, úgy véljük, érdemes foglalkozni a jogalanyiság kérdésével az MI kapcsán is. A jogirodalomban fellelhető olyan álláspont is, amelyik a robotok helyett kifejezetten az Al jogalanyiságával foglalkozik. ${ }^{57} \mathrm{~A}$ továbbiakban a robotok jogalanyiságára vonatkozó álláspontokat is ismertetjük (azonban véleményünk szerint ezek a mesterséges intelligencia kapcsán is értékelést nyernek, gondoljunk csak az önálló döntések meghozatalára képes entitásra, ami nélkül a robot pusztán gép lenne, tehát az eszköz lényegét maga az $\mathrm{Ml}$ adja). ${ }^{58}$

A kérdés kapcsán a szerzők két csoportra oszthatóak. Egyesek kifejezetten szeretnék, hogy az Al valamilyen formában önálló jogalanyiságot, jogi személyiséget nyerjen, míg mások ezt ellenzik, sőt a technológia tekintetében óvatosságra intenek (utóbbiak az ún. alarmisták). ${ }^{59}$

A jogalanyiság vonatkozásában érdemes megemlíteni a jogi személyiség kiterjesztését a nevezett entitásokra. ${ }^{60}$ Ehhez a hazai viszonyokat tekintve kiindulási

${ }^{55}$ ReVOLIDIS-DAHI: i. m., 70-71.

${ }^{56}$ Ide tartozik például Peter B. Scott-Morgan angol-amerikai robotkutató, akit 2017-ben diagnosztizáltak motoneuron betegséggel, amely izomsorvadással jár. A férfi ezt követően határozta el, hogy ő lesz a világ első cyborgja. Az „átváltozás” már elkezdődött, beszéde algoritmusoknak köszönhetöen szintetikussá vált, arcáról pedig élethủ avatárt készítettek. Vö.: Stubley, Peter: Terminally ill scinetist 'transforms himself into world's first full cyborg.' https://www.independent.co.uk/news/science/cyborg-scientist-first-motor-neurone-diseasepeter-scott-morgan-a9201436.html (2019. 12. 22.).

${ }^{57}$ Többek között TURNER, Jacob: Robot Rules - Regulating Artificial Intelligence. Palgrave Macmillan, Cham, 2018, 173-206., Solum, Lawrence B.: Legal Personhood for Artificial Intelligences. North Carolina Law Review, 1992/4, 1231-1287., TEUBNER, Gunther: Digitale Rechtssubjekte? Zum privatrechtlichen Status autonomer Softwareagenten - Digital Personhood? The Status of Autonomous Software Agents in Private Law. Ancilla luris, 2018, 36-78. (DOI: 10.2139/ssrn.3177096).

${ }^{58}$ A téma tekintetében az erkölcsi-etikai kérdések vizsgálata megkerülhetetlen. PuszTAHELYı Réka: Bizalmunkra méltó $\mathrm{MI}$ - A mesterséges intelligencia fejlesztésének és alkalmazásának erkölcsi-etikai vonatkozásairól. Publicationes Universitatis Miskolcinensis, Sectio Juridica et Politica, 2019/2. (megjelenés alatt).

59 Z. KARVALICs László: Mesterséges intelligencia - a diskurzusok újratervezésének kora. Információs Társadalom, 2015/4, 7-41. (DOI: 10.22503/inftars.XV.2015.4.1).

${ }^{60}$ ESzTERI Dániel: A mesterséges intelligencia fejlesztésének és üzemeltetésének egyes felelősségi kérdései. Infokommunikáció és Jog, 2015/62-63, 47-57. 
alapként szolgálhat Moór Gyulának $A$ jogi személyek elmélete című múve. ${ }^{61} \mathrm{Az}$ ott említett elméletekből azonban a mesterséges intelligencia jogalanyisága kapcsán csupán a (közismert) fikciós elmélet értelmezhető.

Mind a hazai, mind a külföldi szakirodalom több jogi szakírója is egybeveti a robotokat és a római rabszolgákat. Úgy vélik, hogy ezen új entitások helyzete azonosítható a római rabszolgákéval. ${ }^{62}$ Álláspontjuk szerint az azonosság gyökere abból ered, hogy mindkét létező önálló, gondolkodásra képes, mégis mások uralma alatt áll. Az elméletet többen azért fogadják el, mert károkozás esetén a felelősségi kérdések megválaszolása így valamivel könnyebb, s a fennálló jogrendszert sem kell drasztikus módosításoknak alávetni. A szerzők az elmélet mellett azzal is érvelnek, hogy károkozás esetén a rabszolgák „saját vagyonukkal” feleltek; peculiumból teljesítettek. Ennek alkalmazása a robotok általi károkozásra is megoldás lehetne. ${ }^{63}$

Ugyanakkor fontos kiemelni, hogy az állítás nem teljesen helytálló, hiszen a rabszolgák károkozása esetén nem ez volt az egyetlen „jóvátételi mód”. Ezen túlmenően fontos különbség, hogy a rabszolgák hús-vér emberek, élölények voltak, nem pedig „gondolkodásra is képes” gépek. A hazai jog szerint az ember születésétől fogva jogképes, hiszen biológiai lény, ám a múltban több olyan időszak is volt, mikor a személyek egy részének jogait korlátozták. A mesterséges intelligencia esetében ennek fordítottja látszik, azért akarják az Al-t jogalanyisággal felruházni, mert várhatóan el fog érni egy, az emberéhez hasonló fejlettségi szintet.

Az Európai Parlament 2017. február 16-án kiadta a robotikára vonatkozó polgári jogi szabályokkal kapcsolatos állásfoglalását. A dokumentum egyik jelentős pontja (59. f pont) arra irányul, hogy a legkifinomultabb autonóm robotoknak akár jogalanyiságot adhassanak; azok olyan elektronikus személyek lehessenek, akiknek jogaik és kötelezettségeik lehetnek - így az általuk okozott kárért való felelősség tekintetében helytállási kötelezettségük keletkezhet. ${ }^{64} \mathrm{~A}$ dokumentum e kezdeményezése igen nagy ellenállásba ütközött. Tudósok, jogászok nyílt levélben tiltakoztak az elektronikus személyiség létrehozása ellen, amely nyomán e törekvések elcsendesedtek. ${ }^{65} \mathrm{Az}$ uniós joganyag azonban azt mutatja, hogy a későbbiekben akár sor kerülhet arra, hogy a mesterséges intelligencia mint jogi személyiséggel bíró alany jelenjen meg a Polgári törvénykönyvben.

Az MI jogalanyisággal történö felruházása azonban ma még távolinak és problematikusnak tünik, mivel egy olyan programról van szó, amelyik meghatározott feladatokat végez el, emberszerü cselekvőként jelenik meg, de mégsem az. ${ }^{66}$

${ }^{61}$ Moór Gyula: A jogi személyek elmélete. A Magyar Tudományos Akadémia Jogtudományi Bizottságának Kiadványsorozata, Budapest, 1931.

62 Revolidis-Dahi: i. m., 69-70.

PagAllo, Ugo: The Laws of Robots - Crimes, Contracts and Torts. Springer, Netherlands, 2013, $102-106$. (DOI: 10.1007/978-94-007-6564-1).

${ }^{63}$ Revolidis-Dahi: i. m., 69-70; PAgallo: i. m., 69-70.

${ }^{64}$ A robotikára vonatkozó polgári jogi szabályok. P8_TA(2017)0051, 59. pont f. http://www.europarl.europa.eu/ doceo/document/TA-8-2017-0051_HU.pdf (2020. 01. 15.).

65 Open Letter to the European Commission Artificial Intelligence and Robotics. http://www.robotics-openletter. eu/ (2020. 01. 15.).

${ }^{66}$ Lásd: Liability for Artificial Intelligence and Other Emerging Digital Technologies. Report from the Expert Group on Liability and New Technologies - New Technologies Formation. European Union, 2019, 37-39. 


\section{3. Összegzés}

A fentiek alapján látható, hogy alapvetően az MI fogalmának általános meghatározása is nehézkes, ezen túlmenően annak jogi értékelése szintén problematikus. Nem lehet egyértelműen meghatározni, hogy az Al polgári jogi szempontból melyik fogalom alá vonható.

A hatályos szabályozás szerint a mesterséges intelligencia szoftvernek minősül. Ezzel szemben olyan feladatok végrehajtására is képes, amelyre más szoftverek, programok nem, hanem csak hús-vér emberek. Tehát olyan többlet-tulajdonságai is vannak, amelyekkel a szoftverek általában nem rendelkeznek. A szoftver immateriális javak körébe tartozó vagyontárgykénti megközelítése érdekes felvetés lehet. Ez látszik a legvalószínübbnek az európai adatpiac létrehozása, és a piaci szempontok miatt is. Ugyanakkor ez a lehetőség a felelősségi kérdések megválaszolásában nem nyújt segítséget.

Az MI dologként való értékelése szintén nem megfelelő, hiszen a dologi minőség egyik legfontosabb feltétele - a fizikai megjelenés - hiányzik. Még ha ettől az esszenciális összetevőtöl eltekintenénk is, akkor is pusztán analógia vagy fikció útján lehetne kiterjeszteni a technológiára mint dologra vonatkozó szabályokat. (Ennek a jogi megoldásnak az alkalmazására korábban már sor került a villamos áram kapcsán.)

A technológia jogalanyként való azonosítása sem egyértelmü. Egyrészt mivel az erkölcsi-etikai szempontból problematikus, másrészt pedig mert hiába viselkedik emberszerüen, mégsem minősül annak, mivel mesterségesen - nem biológiai úton hozták létre. Az MI és a rabszolgák közötti párhuzam álláspontunk szerint szintén aggályos, mivel a rabszolgák természetes személyek voltak, ezzel szemben a mesterségesintelligencia-rendszerek vagy robotok pedig különböző adatokból, forráskódokból, alkatrészekből összeállított „létezők”.

Megoldás lehet a már meglévő definíciók használata akként, hogy azokat módosítják, illetőleg egyszerüen kiterjesztően értelmezik. Esetleg sor kerülhet egy teljesen új jogintézmény felállítására is. Ez utóbbi elfogadható lenne, hiszen egy olyan új technológiáról beszélünk, amelyhez hasonlóra sem volt példa korábban az emberiség történelmében. A probléma feloldásában hatékony lehet továbbá az is, ha az egyes mesterséges intelligenciák között fejlettségük szerint differenciálunk, s ez alapján definiáljuk azokat az egyes jogterületeken, különösen a polgári jogi jogintézmények tekintetében. Tehát kifejezetten csak azokon a területeken, ahol a definiálásnak tényleges relevanciája van. Ez alapján egy meghatározott feladat végrehajtására szolgáló MI akár dolog is lehet, míg egy fejlett, önálló döntéshozatalra képes Al akár jogalanyiságot is nyerhet a későbbiekben.

További megoldás lehet a szektoriális szabályozás kialakítása, ennek körében egy, a szerzői jogi törvény mintájára elkészített külön törvény létrehozatala, amelyik kifejezetten az MI-re vonatkozó szabályokat tartalmaz. Így a jogrendszer átfogó átalakítása nélkül is feloldhatóak lehetnének az új technológiával kapcsolatos nehézségek. Ezen kívül a felelősségi kérdések kapcsán a kötelező gépjármű-felelősségbiztosítás mintájára külön, az Al-ra vonatkozó felelősségbiztosítás létrehozása is megfelelő eszköz lehet.

(DOI: 10.2838/57368937-39.) https://ec.europa.eu/transparency/regexpert/index.cfm?do=groupDetail. groupMeetingDoc\&docid=36608 (2020. 02. 04.). 